TI 2011-071/3

Tinbergen Institute Discussion Paper

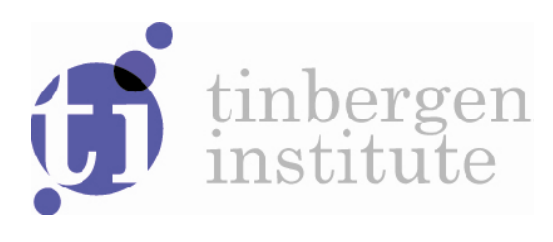

The Crisis Sensitivity of European Countries and Regions: Stylized Facts and Spatial Heterogeneity

Stefan P.T. Groota,c

Jan Möhlmanna

Harry Garretsen ${ }^{b}$

Henri L.F. de Groota,c,d

\author{
a VU University Amsterdam; \\ b University of Groningen; \\ c Tinbergen Institute; \\ a Ecorys NEI, Rotterdam; \\ all in The Netherlands.
}


Tinbergen Institute is the graduate school and research institute in economics of Erasmus University Rotterdam, the University of Amsterdam and VU University Amsterdam.

More TI discussion papers can be downloaded at http://www.tinbergen.nl

Tinbergen Institute has two locations:

Tinbergen Institute Amsterdam

Gustav Mahlerplein 117

1082 MS Amsterdam

The Netherlands

Tel.: +31(0)205251600

Tinbergen Institute Rotterdam

Burg. Oudlaan 50

3062 PA Rotterdam

The Netherlands

Tel.: +31(0)10 4088900

Fax: +31(0)104089031

Duisenberg school of finance is a collaboration of the Dutch financial sector and universities, with the ambition to support innovative research and offer top quality academic education in core areas of finance.

DSF research papers can be downloaded at: http://www.dsf.nl/

Duisenberg school of finance

Gustav Mahlerplein 117

1082 MS Amsterdam

The Netherlands

Tel.: +31(0)20 5258579 


\title{
The Crisis Sensitivity of European Countries and Regions: Stylized Facts and Spatial Heterogeneity
}

\author{
Stefan P.T. Groot ${ }^{\mathrm{a}}$, Jan Möhlmann ${ }^{\mathrm{a}}$, Harry Garretsen ${ }^{\mathrm{b}}$ and Henri L.F. de Groot ${ }^{\mathrm{a}, \mathrm{c}, \mathrm{d}, 1}$ \\ ${ }^{a}$ Dept. of Spatial Economics, VU University Amsterdam, Amsterdam, The Netherlands \\ ${ }^{\mathrm{b}}$ Faculty of Economics \& Business, University of Groningen, Groningen, The Netherlands \\ ${ }^{c}$ Tinbergen Institute, Amsterdam-Rotterdam, The Netherlands \\ ${ }^{\mathrm{d}}$ Ecorys NEI, Rotterdam, The Netherlands
}

April 2011

\begin{abstract}
This paper investigates the impact of the recent global recession on European countries and regions. We first present several stylized facts as to the heterogeneous impact of the global recession on individual European countries and regions. We then offer an investigation of three main classes of explanations for spatial heterogeneity in the severity of the crisis. The first is the extent to which countries are integrated in the global economy via financial and trade linkages. A second class of potential explanations is found in differences in the institutional framework of countries. A third possible cause why some countries and notably also regions are more affected than others is differences in their sectoral composition. We show that especially variation in the sectoral composition contributes to the variation in the effects of the current crisis, both at the country level and at the detailed regional level across the EU.
\end{abstract}

JEL codes: $\quad$ E02, E32, E63, F44, O52, R11

Key-words: recession, austerity, Europe, spatial heterogeneity

\footnotetext{
${ }^{1}$ Corresponding author: Henri L.F. de Groot, Dept. of Spatial Economics, VU University Amsterdam, De Boelelaan 1105, 1081 HV Amsterdam, The Netherlands, Email: h.l.f.de.groot@vu.nl. Useful comments by Ton van Schaik are gratefully acknowledged. The usual disclaimer applies.
} 


\section{Introduction}

The financial crisis that hit the global economy in 2008 marked the start of the most serious economic crisis since the 1930s. Now that the dust has settled somewhat, the first empirical analyses of macroeconomic performance during and immediately after the crisis have appeared and they reveal a large heterogeneity across countries (see, for example, Lane and Milesi-Ferretti, 2010; Rose and Spiegel, 2010; and Claessens et al., 2010). Looking at a large cross-section of countries, Lane and Milesi-Ferretti (2010) study the severity of the crisis as - among other things - a function of the openness of the countries and their fiscal situation before the crisis. Taking their analysis as a starting point, this paper aims to dig deeper into the impact of the recession on European regions and the sources of variation of this impact. ${ }^{2}$ In contrast to, for instance, Lane and Milesi-Ferretti (2010) we do not only look at GDP but also consider unemployment changes. Furthermore, in view of the huge spatial inequalities across European regions, we also look at the sub-national level. Finally, we consider a much more refined sectoral level than used in Lane and Milesi-Ferretti (2010).

Our paper makes no claim to offer a full-fledged answer to the relevance of the determinants of regional impacts of the 2008-crisis but, and by using the latest data available, we aim to present a number of relevant stylized facts about the cross-country and cross-regional differences of the latest crisis so to enhance our understanding of their possible determinants. To the best of our knowledge, the present paper is one of the first to thoroughly examine the role of institutions as an explanation for cross-country variation in the effects of the crisis.

In order to contribute to the emerging literature on the mechanisms through which the 2008-2009 global recession spread across regions, we take three different, complementary perspectives. The first two of these are mainly operational at the national level, whereas the third one (viz. sectoral composition) has a clear relevance at the sub-national regional level as well. ${ }^{3}$ Furthermore, we contribute to the "fiscal austerity" theme of this issue of the journal, by looking into the relevance of fiscal policy. The latter will be done at the country level since regional data on fiscal policy measures across the EU are difficult to obtain and also because the variation in fiscal policy or austerity measures is mainly relevant between and not so much within countries.

We start by putting the focus on the international context of the crisis, looking at financial linkages and trade linkages between countries, which is the first of our three perspectives. Our findings show that such linkages provide at best a partial explanation for the depth of the crisis in different countries, but leave much unexplained. Second, we analyse whether cross-country differences in institutions explain the spread of the crisis. Finally, we focus on differences in the sectoral composition to explain

\footnotetext{
${ }^{2}$ Countries in our sample are, in sofar as data are available, member states of the EU-27, plus Iceland, Norway and Switzerland, which are well integrated to the European single market. Due to data limitations, some of our analyses are based on subsamples of these countries.

${ }^{3}$ Our paper is related to the recent literature on the resilience of countries and regions to economic shocks like recessions. The resilience literature focuses on the (differential) impact and/or recovery of locations to economic shocks over time. See, for instance, Cerra and Saxena (2008), Fingleton et al. (2011) or, on a more conceptual level, a recent issue of this journal (Cambridge Journal of the Regions, Economy and Society, 2010). Our focus here is on a single shock (the 2008 recession) and its determinants.
} 
differences in the severity of the crisis both within and between countries. The latter will be done by looking at NUTS-1 and NUTS-2 regions. We find that differences in the sectoral composition explain a substantial part of variation of the crisis or recession impact across the EU regions. Although we do not offer anything like a full blown analytical model of the causes and consequences of the recent financial crisis and the ensuing recession, we feel that that our 3 main determinants of cross-country or crossregional variation of the real impact of the crisis (openness, institutional make up, and sectoral composition) constitute a useful decomposition of possible sources of variation in the real impact of the crisis.

\section{Impact of the crisis on GDP and unemployment in different regions}

Since the start of the global recession in late 2008, almost all advanced economies experienced a reduction of output and increased unemployment. In the 27 member states of the European Union (EU27), real GDP decreased by 5.3 percent between the first quarter of 2008 and the second quarter of 2009: roughly a set back to the 2006 level (see Figure 1). There are, however, large cross-country differences in both the timing and the depth of the crisis and subsequent recovery.

Figure 1. Index of real GDP in the EU-27 (2005Q1 = 100)

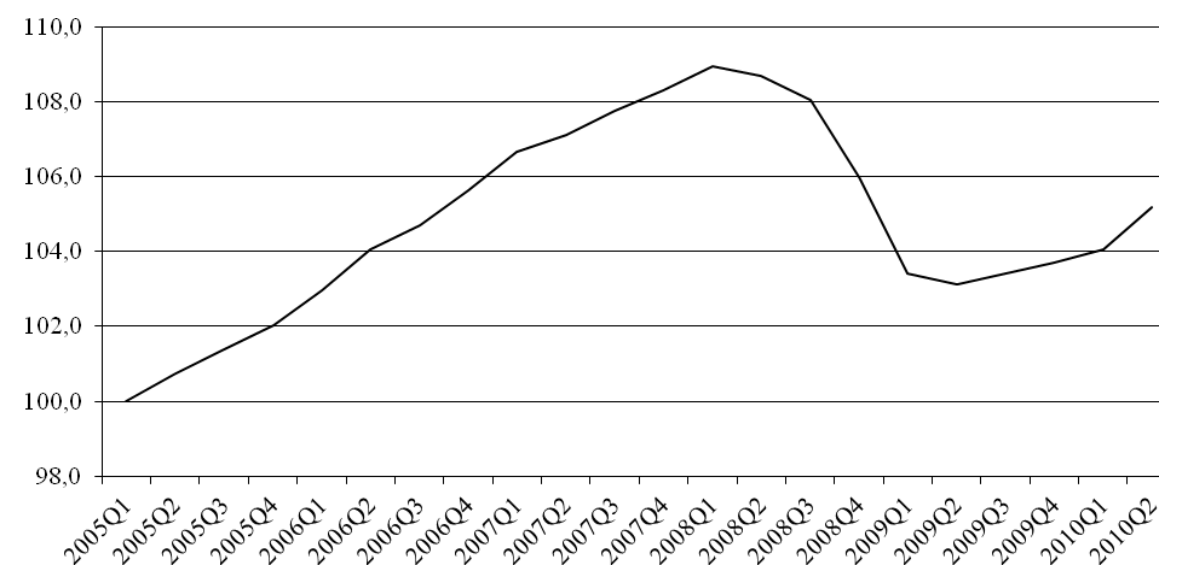

Source: Eurostat, Quarterly National Accounts statistics, December 2010

The heterogeneity by which the 2008 crisis manifested itself in the different member states is illustrated in Figure 2. The left part of this figure shows the maximum decline in GDP for each country during the recession. The start of the recession is defined as the first quarter in which (seasonally adjusted) GDP declined for at least two subsequent quarters. The end of the recession is defined as the last quarter before GDP started to recover. We thus define the recession separately for each individual country. The figure also shows the change of GDP between the last available quarter (2010Q2) and the pre-crisis GDP level. This provides a first insight in the recovery phase. The effect of the recession differs in both depth and duration. For example, Ireland experienced a decline of GDP of 14.3 percent during the recession, which lasted from 2008Q1 until 2009Q4. In Norway, the recession was shorter by four quarters (2008Q3-2009Q2) and was less intense, with a GDP decline of only 2.2 percent. In the second quarter of 2010, which is the last quarter for which data are available, almost all countries have 
started to recover from the crisis. Greece is the only country that was officially still in a recession back then, and Ireland's GDP started to decline again after only one quarter of growth. Some countries are already approaching their pre-crisis GDP level, while others are recovering much more slowly. The current government debt crisis, which forces harsh budget cuts in several EU countries, and the persistent euro crisis may further delay recovery in several countries for years to come.

The right part of Figure 2 shows the change in the unemployment rate during the recession and the change between the quarter before the recession and the last available quarter (2010Q2). In most European countries, unemployment rates started to increase shortly after their economies entered into recession. Unemployment usually follows GDP with some delay, with unemployment typically increasing relatively fast about when GDP starts to recover again, and unemployment often still increasing gradually for one or more years afterwards. Figure 2 reveals that unemployment was still increasing in most countries in the second quarter of 2010. A notable exception to the general rule is Germany, where unemployment rates actually started to decline when it entered the recession. As the following section reveals, this may be partially explained by the structure of the German labour market, as well as a favourable ratio between labour productivity and labour costs in Germany.

Figure 2. Spatial heterogeneity in the effects of the crisis: change (in \%) of GDP (left panel) and change (in \%-point) of unemployment (right panel) relative to the pre-crisis level
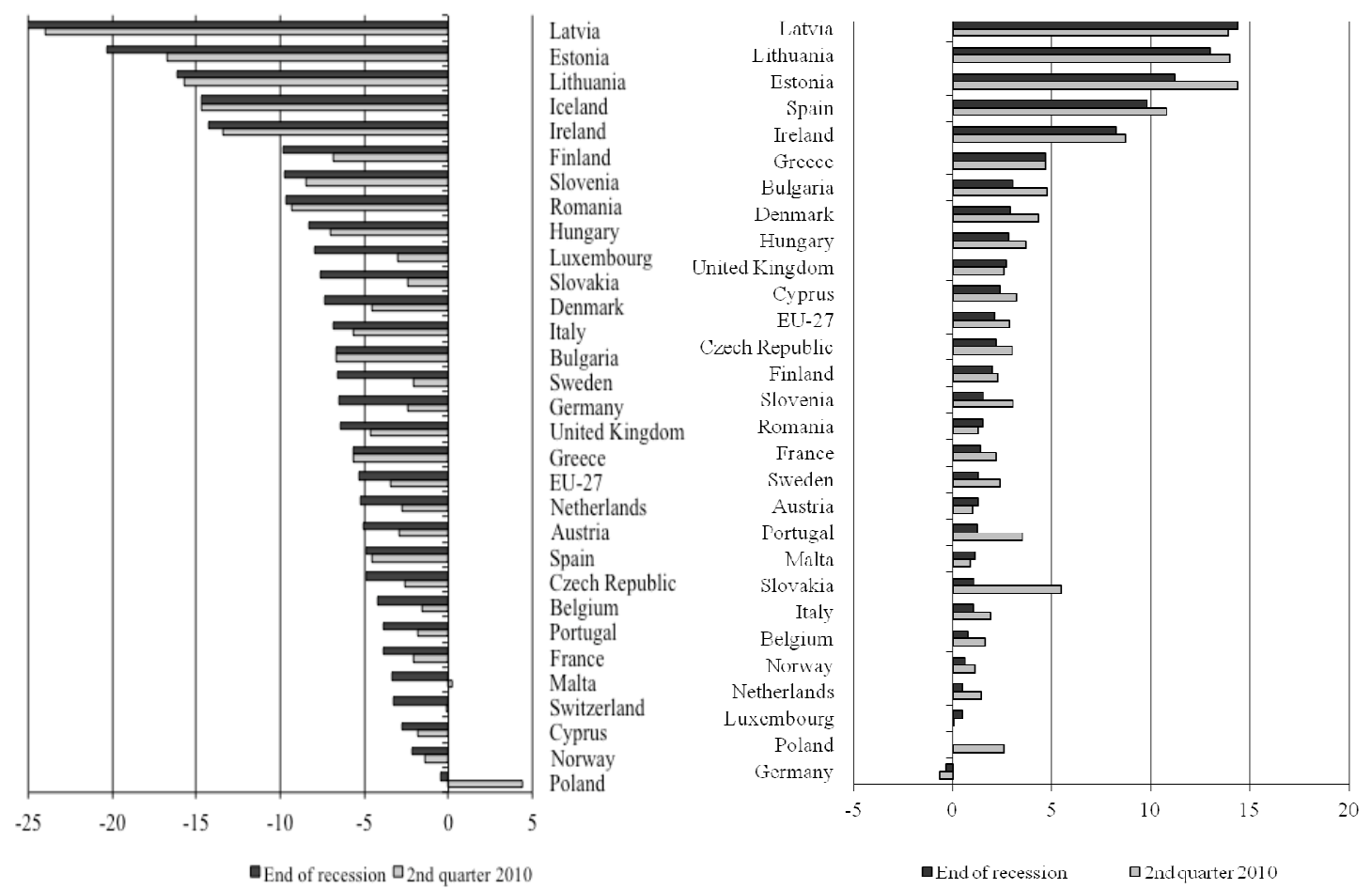

Source: Eurostat, Quarterly National Accounts statistics, December 2010

Not only do European countries differ substantially as to how severe they were hit by the crisis, but there is also considerable heterogeneity in the ratio of the change in GDP and the change in unemployment, as is shown in Figure 3. Germany and Spain, for example, are both large economies 
within the euro zone with output reductions close to the EU average. German GDP decreased by 6.5 percent during the crisis while the reduction of Spanish GDP was slightly lower at 4.9 percent. However, while German unemployment rates decreased by a mere 0.3 percentage points, Spanish unemployment rates soared by 9.8 percentage points. To put these numbers in some perspective, we can rely on the simple but often-used and powerful Okun's law, which describes - on a purely statistical basis - the empirical regularity between the GDP growth $(\Delta Y / Y)$ and the change in the unemployment rate $\Delta U$ according to the following equation:

$$
\Delta Y / Y=k+c \Delta U
$$

The parameters for $k$ and $c$ are found to be -4.1 and -1.1 , respectively. This implies that a one-percent increase in the unemployment rate is - on average - associated with a 1.1 percent lower GDP growth rate. Using a large data set on previous more moderate recessions Prachowny (1993) finds the coefficient $c$ to be in the range of -2 to -3 , which implies that the increase in unemployment relative to the GDP decrease is higher in our sample than what was found by Prachowny (1993). ${ }^{4}$ This result is in line with previous studies that have found that financial crises have a stronger impact on unemployment than regular recessions (Reinhart and Rogoff, 2009; IMF, 2010). A possible explanation is that just like an adverse technology or supply shock, financial crises hamper the normal workings of the financial system to the extent that the potential production capacity is (permanently) reduced. Furthermore, as financial crises tend to last longer than regular economic downturns, retaining employees to enable a quick resumption of production when demand increases again may be more costly.

Figure 3. Relationship between change in GDP and change in unemployment

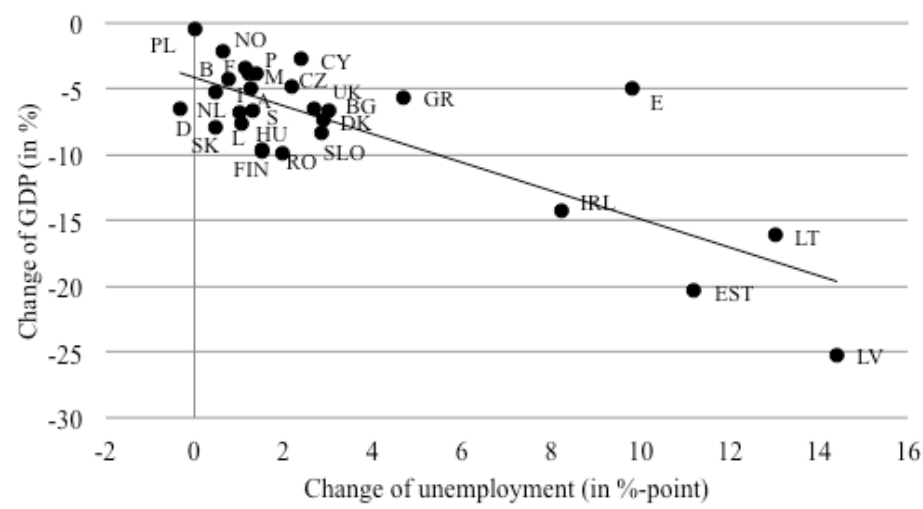

Note: See Appendix B for a list of abbreviations of countries

Before we turn to an explanation or, more accurately, a decomposition of the observed heterogeneity, it is useful to see which workers were especially affected by the recession. Sensitivity to business cycles

\footnotetext{
${ }^{4}$ Some care is required in comparing these estimates. Our estimates are based on a cross-sectional specification, using the length of the official recession in each country as the reference period, whereas the estimates of Prachowny (1993) are estimated on time series. A more systematic analysis controlling for differences in sample, time period and exact estimation techniques would be required to draw stronger conclusions.
} 
is twice as high for younger workers than for workers between 25 and 54 (Keeley and Love, 2010). Workers on temporary jobs are also much more likely to lose their jobs (because of lower costs of firing). Finally, workers employed in industries that are sensitive to the business cycle are more likely to become unemployed, which is the topic of Section 5. In Spain, the loss of temporary jobs accounts for 85 percent of the total change of unemployment (Keeley and Love, 2010). Figure 4 compares the deviation from Okun's law - defined as observed change of unemployment minus the expected change of unemployment that would correspond to the observed reduction of GDP - to the incidence of temporary employment according to the OECD Employment Outlook (OECD, 2010a) before the crisis. In Spain, GDP decreased by 4.9 percent during the crisis, which is associated to 4.1 percent-point higher unemployment based on the coefficients estimated for equation (1). As unemployment increased by 10.8 percent in reality, unemployment change was 6.7 percent higher than expected. The incidence of temporary employment - which is partially related to institutions and partially to the structure of the labour market in general - provides a partial explanation for the deviation of relative outlier Spain from the aforementioned well-established empirical regularity, Okun's law.

Figure 4. Relationship between temporary unemployment and the deviation from Okun's law

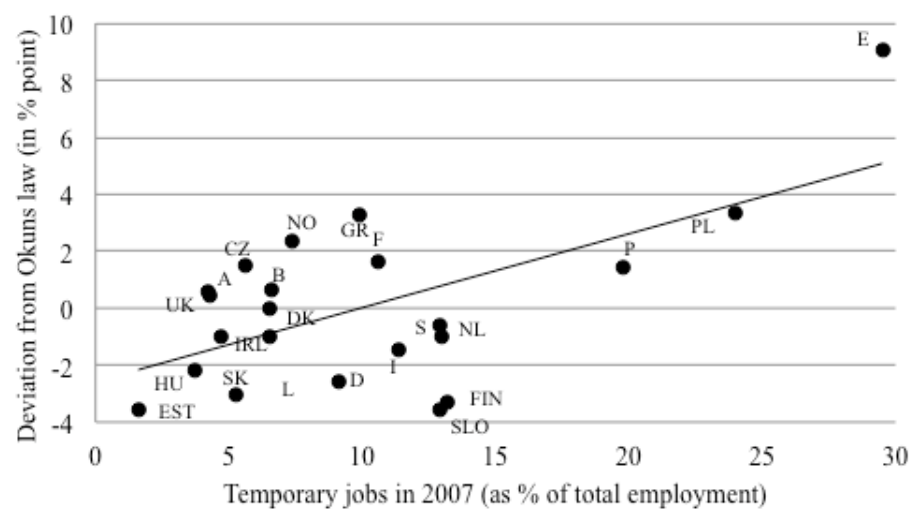

Note: See Appendix B for a list of abbreviations of countries

\section{Financial markets and international trade linkages}

The global financial crisis that erupted in late 2008 and the subsequent were triggered by a mortgage crisis in the United States. The latter quickly spread to other countries, due to the advanced financial and economic integration of countries throughout the world. Reduced solvability of banks in combination with uncertainty as of the value of financial assets reduced bank lending, led to a global credit crunch. This affected the real economy through reduced consumers spending and investments. ${ }^{5}$

To empirically assess the potential relevance of the financial transmission channel, we consider two indicators. The first is the size of government support to the banking sector as a proxy for the size of the credit crunch in the countries. Note that this indicator is not fully exogenous, since banks may

\footnotetext{
${ }^{5}$ Studies on the recent crisis by Lane and Milesi-Ferretti (2010) and by Claessens et al. (2010) suggest that instead of financial integration in general, very specific financial factors - like asset booms - provide some explanation for the severity of the crisis.
} 
require more support when economic growth decreases more. However, it is likely that the main reason that banks required support was a decreasing value of existing financial assets. Note that the bulk of the government support came about in late 2008 just before the downturn of the real economy kicked in. Data on government support for the financial sector are from the OECD (2010b). These data contain the amount of capital injections, purchases of assets and lending by the treasury, and government guarantees, all up to August 2009 and expressed as a percentage of 2008 GDP. Since these are conceptually different forms of support, we created a weighted sum with weights of 1,1 and 0.2 , respectively. Second, in order to test whether wealth effects have affected the depth and duration of the recession, we focus on the housing market. To avoid endogeneity, we do not look at the actual decrease of housing prices, but rather to the development of housing prices before the crisis, as an indication for the likelihood of decreasing housing prices. We use a measure for the overvaluation of housing prices, which was constructed by the IMF (2008). It is based on the change of housing prices and the changes in several structural indicators, like disposable income, interest rates, and working-age population, in the period 1997-2007. ${ }^{6}$

Simple correlation coefficients between these two indicators and the depth of the crisis in terms of (subsequent change in) GDP and unemployment are shown in Table 1 (rows 1 and 2). Especially the index for government support for financial institutions is strongly negatively correlated with GDP change. This suggests a rather large credit crunch effect. However, the correlation is for a large part caused by Ireland. The same applies to the correlation with the unemployment change. The housing price gap does not strongly correlate with the change in GDP, but it is positively correlated with the change in unemployment. Figure 4 shows a scatter diagram of the government support to the financial sector and the change in GDP and unemployment.

Table 1. Simple correlations between financial indicators (rows 1-2), trade linkages (rows 3-8) and dept of the crisis (columns)

\begin{tabular}{lrr}
\hline & $\begin{array}{r}\text { Maximum change } \\
\text { of GDP (in \%) }\end{array}$ & $\begin{array}{r}\text { Maximum change of } \\
\text { unemployment (in \% point) }\end{array}$ \\
$\begin{array}{lr}\text { (1) Index for government support relative to GDP } \\
\text { (2) Housing price gap }\end{array}$ & $-0.66(0.01)$ & $0.39(0.15)$ \\
(3) Exports as percentage of GDP & $-0.05(0.80)$ & $-0.36(0.28)$ \\
(4) Imports as percentage of GDP & $-0.20(0.28)$ & $0.10(0.62)$ \\
(5) Current account balance (average 2004-2007) & $0.49(0.01)$ & $-0.59(0.00)$ \\
(6) Exports to the United States as percentage of GDP & $-0.13(0.49)$ & $0.11(0.57)$ \\
(7) Exports to Asia as percentage of GDP & $0.19(0.30)$ & $-0.14(0.48)$ \\
(8) Change of unit labour costs (2001-2007) & $-0.69(0.00)$ & $0.59(0.00)$
\end{tabular}

Note: $p$-values are between parentheses.

\footnotetext{
${ }^{6}$ For an analysis how the 2008 financial crisis, with an emphasis on the banking crisis, also had a strong regional impact within countries, see Martin (2010).
} 
Figure 4. Relationship between government support for the financial sector and the change of GDP (upper panel) and unemployment (lower panel)
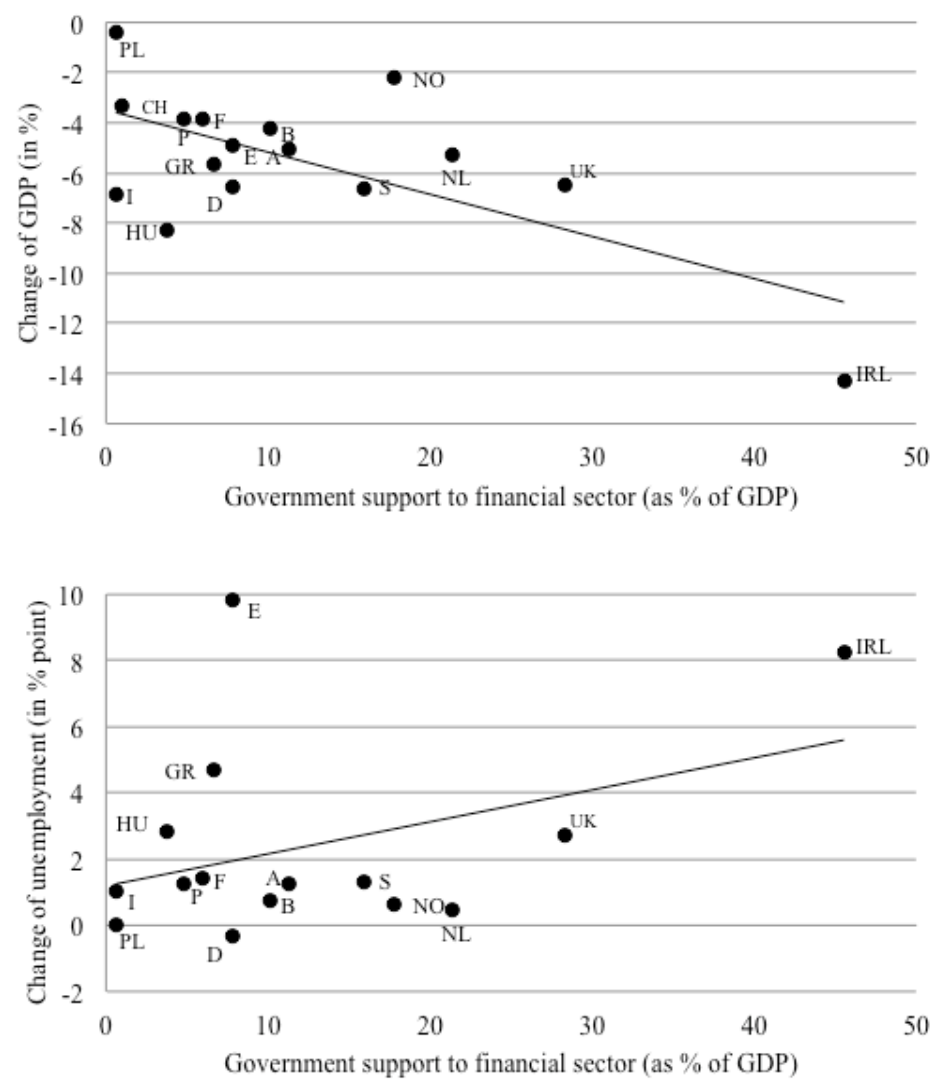

Note: See Appendix B for a list of abbreviations of countries

Besides the international financial linkages, the recession could also spread due to the international trade linkages. When the United States for instance entered into recession, this reduced demand for exports in other countries. Rose and Spiegel (2010) suggest that trade linkages were actually more important in spreading of the crisis than financial linkages. As global trade collapsed during the first few years of the crisis, it is reasonable to suspect that countries with a higher export share experienced more severe reductions in output due to lower demand for their exports. Indeed, Lane and MilesiFerretti (2010) and Claessens et al. (2010) find that trade openness is (moderately) associated with higher output reduction. Their measure of openness is exports plus imports divided by GDP. Based on our sample of countries we find that the amount of exports relative to GDP (row 3 in Table 1) is only weakly negatively correlated to the change of GDP, while higher imports (row 4 in Table 1) are a somewhat stronger associated with output reduction. The current account balance is even stronger correlated with the depth of the recession. The average current account balance in the period 20042007 (row 5 in Table 1) has a correlation of 0.49 with the change of GDP.

Figure 5 presents two scatter plots, in which the change of GDP and the change of employment during the crisis are plotted against the pre-crisis current account balance. Figure 5 clearly suggests a positive 
and statistically significant relationship between the pre-crisis current account balance and the impact of the crisis. This finding is in line with much of the literature that finds that trade imbalances are a good predictor of the severity of future crises (see Kaminsky and Reinhart, 1999). Countries with a surplus on the current account balance before the crisis on average experience a smaller decline of GDP and a smaller increase of unemployment. This reflects that the current account balance and trends in unit labour costs are important indicators for the competitiveness of countries on world markets (the two indicators are highly correlated according to Table 1). Countries with a surplus on the current account are more competitive. When global demand falls, particularly large effects can be expected in less competitive countries, both in terms of GDP and unemployment. Not only has the financial crisis made it more difficult to finance large current account deficits, countries with high labour costs relative to productivity are also a more likely target for multinationals that are downscaling their operations.

Figure 5. Relationship between the current account balance and the change of GDP (upper panel) and unemployment (lower panel)
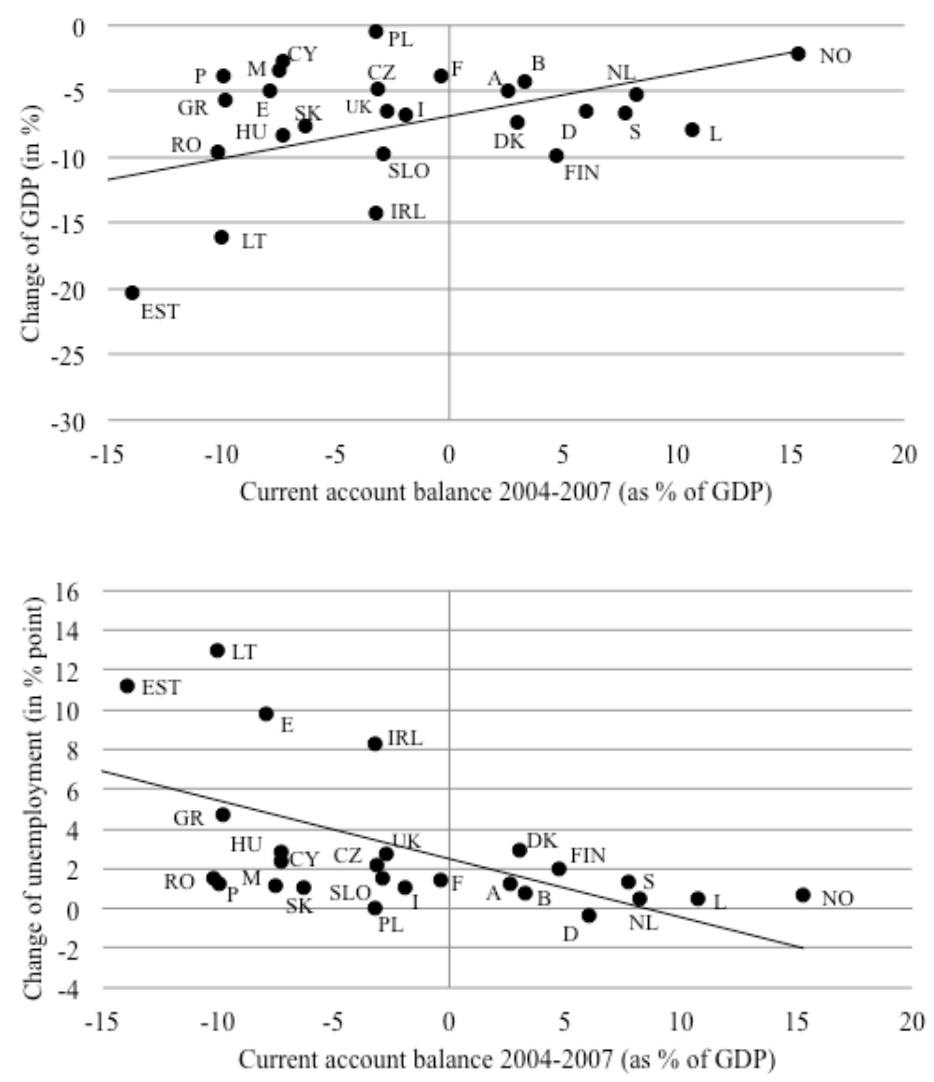

Note: See Appendix B for a list of abbreviations of countries

Another possible trade related explanation for the cross-country variation in the depth of the crisis is the composition of trading partners. Since the crisis was initiated by the housing market in the United States, it is often thought that countries with high exports to the United States are also among the countries which are most affected by the crisis. Similarly, it is well conceivable that countries with relatively strong exports to Asia where the impact of the crisis was relatively small suffered to a 
relatively limited extent. We do indeed find that the ratio between exports to the United States and GDP is negatively associated with GDP change and positively associated with unemployment change (row 6 in Table 1). The opposite holds for the ratio between exports to Asia and GDP (row 7 in Table 1). Although these signs are consistent with expectations, the correlations are statistically insignificant.

The last indicator from Table 1 that shows a significant correlation with the depth of the crisis is the change of real labour costs in the years prior to the global recession (row 8 in Table 1). This measure is defined as the change in the ratio between GDP and labour costs. If we exclude Romania, which is an outlier with real labour costs increasing by as much as 82 percent between 2001 and 2007, the correlation with change in GDP during the recession becomes -0.79 , and with the change in unemployment rates during that period 0.78. Figure 6 shows the scatter plots for the relationship between the change in labour costs and the output and unemployment effect of the current crisis. The reduction of real labour costs in Germany in the years prior to the crisis may explain why unemployment did not increase.

Figure 6. Relationship between change in labour costs and the change of GDP (upper panel) and unemployment (lower panel)
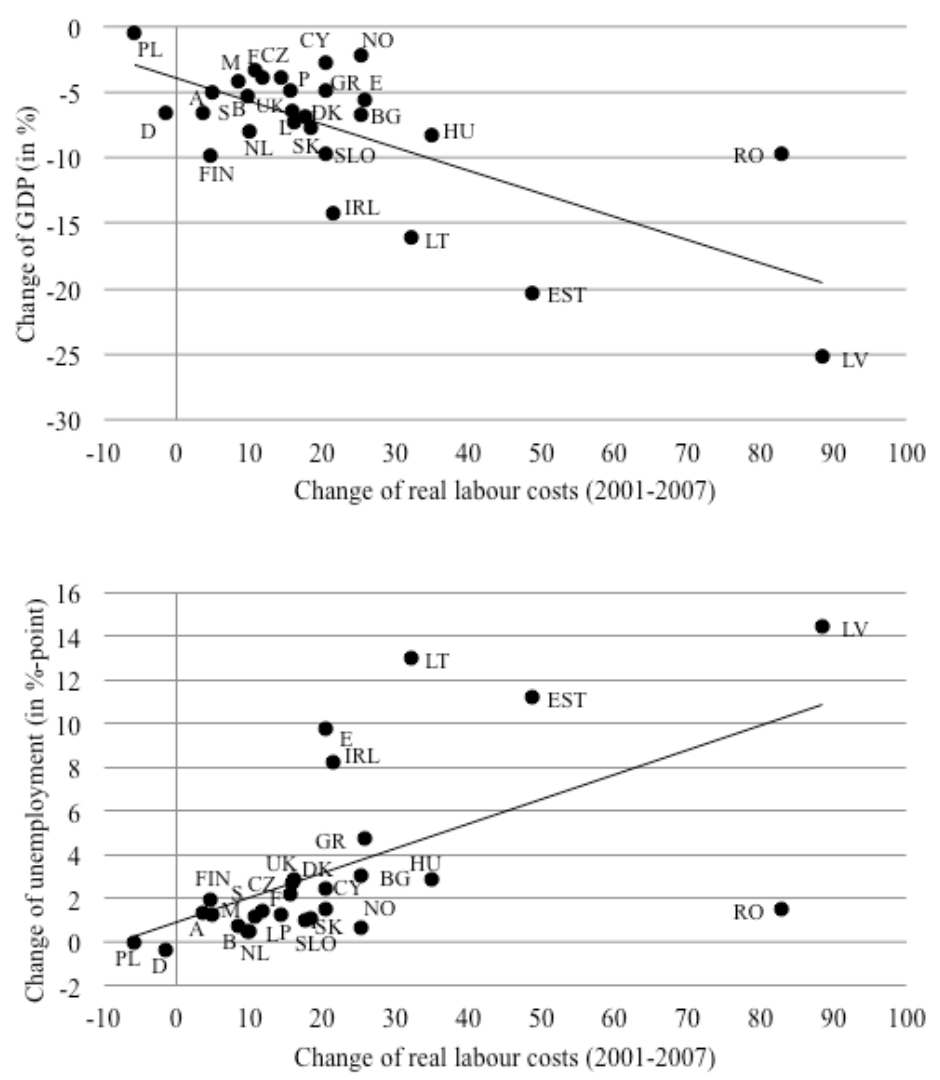

Note: See Appendix B for a list of abbreviations of countries 


\section{Institutions and the current crisis}

We now turn to the second potential factor in decomposing the cross-country variation in the extent of the crisis, viz. differences in the institutional framework. Institutions play an important role in defining the economic landscape in countries, and even within Europe there are substantial differences in the quality of institutions. ${ }^{7}$ Institutions are known to be especially important in explaining variation in unemployment (see, for example, De Groot et al., 2006). Some structural policies such as flexible labour markets that reduce unemployment and increase GDP growth in the long run, may increase the severity of a crisis in the short run. If the costs of firing employees are higher, firms are more likely to retain employees during a recession, which makes final demand less sensitive to the business cycle. As government spending tends to be slightly contra cyclical, a larger government may dampen the reduction in demand. In this section, we relate a rich and diverse set of dimensions of institutions to trends in GDP growth and unemployment in different countries. An indicator that is particularly interesting is the deviation of the actual change in unemployment from the expected change given the estimated relation between the change in GDP and the change in unemployment (Okun's law; see Section 2).

We start by presenting in Table 2 some simple correlation coefficients between key variables. Recall, that we not claim to offer a model or causal explanation of how, in this case, institutions determine the severity of the recession, we are merely presenting a number of facts. Appendix A lists the indicators that we have available, which include different measures related to fiscal austerity (rows 1-4), labour market institutions including employment protection, and the strength of trade unions (rows 5-11), and product-market regulation (row 12). In addition, we look at the effects of short-time work arrangements that have been implemented or extended in response to the financial crisis (row 13).

\footnotetext{
${ }^{7}$ For an example of the institutions used, see for instance the Rule of Law index as developed by the World Bank: http://www.worldbank.org/wbi/governance/govdata/index.html
} 


\begin{tabular}{lrrr}
\hline & $\begin{array}{r}\text { Maximum change } \\
\text { of GDP (in \%) }\end{array}$ & $\begin{array}{r}\text { Maximum change } \\
\text { of unemployment } \\
\text { (in \% point) }\end{array}$ & $\begin{array}{r}\text { unemployment (in } \\
\text { \% point) from } \\
\text { Okun's law }\end{array}$ \\
(1) Budget surplus as percentage of GDP & $0.01(0.97)$ & $-0.06(0.77)$ & $0.02(0.92)$ \\
(2) Government debt as percentage of GDP & $0.56(0.00)$ & $-0.42(0.03)$ & $0.35(0.07)$ \\
(3) Marginal tax rate (corporate) & $0.39(0.03)$ & $-0.33(0.09)$ & $0.17(0.37)$ \\
(4) Marginal tax rate (income) & $0.33(0.07)$ & $-0.33(0.08)$ & $0.12(0.54)$ \\
(5) Average job tenure & $0.39(0.08)$ & $-0.18(0.45)$ & $0.12(0.64)$ \\
(6) Share of temporary jobs & $0.40(0.05)$ & $0.02(0.92)$ & $0.61(0.00)$ \\
(7) Share of government jobs & $-0.02(0.94)$ & $-0.11(0.67)$ & $-0.05(0.85)$ \\
(8) Employment protection index & $0.38(0.07)$ & $-0.12(0.59)$ & $0.38(0.08)$ \\
(9) Spending on active labour market policies & $0.27(0.17)$ & $-0.19(0.34)$ & $0.19(0.33)$ \\
(10) Ratio between youth and 25-54 unemployment & $-0.17(0.41)$ & $-0.13(0.56)$ & $-0.03(0.90)$ \\
(11) Trade union membership & $-0.48(0.02)$ & $-0.12(0.62)$ & $-0.34(0.15)$ \\
(12) Product market regulation index & $0.20(0.37)$ & $-0.16(0.50)$ & $0.02(0.93)$ \\
(13) Enrolment in short-time work schemes & $-0.11(0.63)$ & $-0.25(0.28)$ & $-0.34(0.15)$ \\
\hline Note: $p$-values are between parentheses. & & &
\end{tabular}

The highest correlation coefficients between GDP change and the institutional indicators (column 1) are found for pre-crisis government debt relative to GDP (0.56), trade union membership (-0.48) and the marginal corporate tax rate (0.39). Unemployment change (column 2) is only significantly correlated to pre-crisis government debt (with a correlation coefficient of $(-0.42)$, while the deviation of unemployment from Okun's law (viz. the deviation from the unemployment rate that is predicted given the change in GDP) is only significantly related to the share of temporary jobs in the labour market (with a coefficient of 0.61 according to column 3).

\subsection{Fiscal austerity and government debt}

A higher government debt and higher tax rates might be considered as proxies for an active government in smoothing demand and a relatively strong willingness to implement Keynesian policies. The findings suggest that countries with such governments indeed face a less severe crisis in the shortrun. The budget surplus during the crisis is uncorrelated to the severity of the crisis. The budget surplus during the recession is, however, highly endogenous: because of automatic stabilizers countries that experience a more severe recession are likely to have a higher budget deficit. The built-in negative correlation with the severity of the crisis may have been netted out by allowing a higher budget deficit during the crisis. Figure 7 shows scatter plots for the relation between pre-crisis government debt with GDP change (upper panel) and unemployment change (lower panel). It should be emphasized that these figures show an interesting relationship without claiming any conclusions regarding the direction of causality. 
Figure 7. Change of GDP (upper panel) and unemployment (lower panel) and pre-crisis government $\operatorname{debt}(\%$ GDP, 2007).
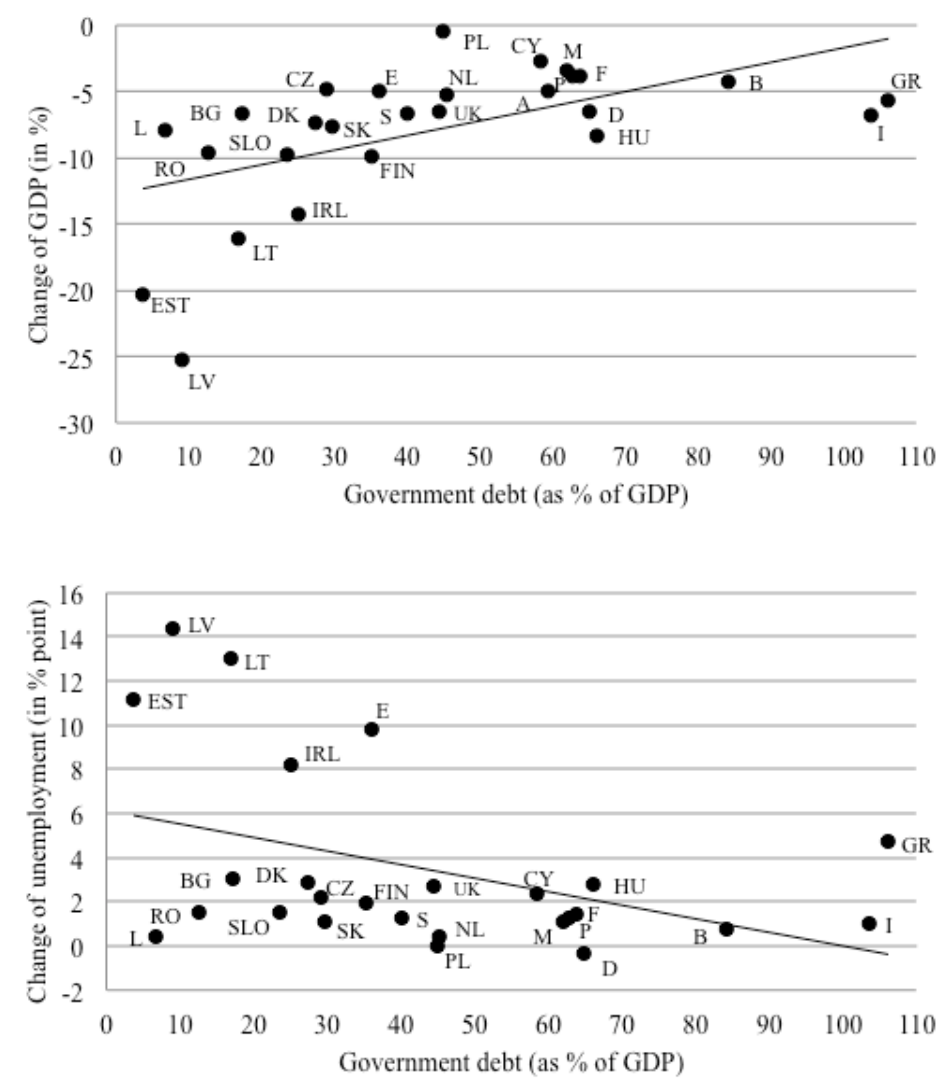

Note: See Appendix B for a list of abbreviations of countries

Contrary to popular belief, countries with a high initial government debt on average experienced a smaller decline of GDP as well as a smaller increase of unemployment during the crisis. Many of the countries that were hit the most by the crisis, like Latvia, Estonia, Lithuania, Ireland, actually had one of the lowest government debt-to-GDP ratios in 2007. The correlation of initial government debt with the deviation of the change of unemployment from Okun's law, however, is positive. This implies that countries with a higher initial government debt experienced a larger change in unemployment than would be expected from the observed decline in GDP. A possible explanation for the observation that countries with an initially lower government debt ratio are hit more severely by the crisis could be that a tighter (pre-crisis) fiscal stance signals that these countries are traditionally prone to relatively prudent or strict fiscal policies. In the wake of the 2008-crisis such a tradition of fiscal austerity may have led to a larger decline of GDP compared to countries that adopted a more accommodating fiscal stance. In the long run, however, a moderation of government debt ratios may be preferable, since a country may risk a prolonged recession when financial markets loose faith in the sustainability of government debt which may force government to even more austerity measures. 


\subsection{Labour market flexibility}

Similar to the issue of fiscal austerity, the way in which labour market institutions affect the economy may differ between the short and the long run. Employment protection and strong trade unions make employers more reluctant to hire in the long run, whereas they are more likely protect employment in the short run. Even though the drop in income may be low due to unemployment benefits, higher uncertainty when more workers are fired is likely to result in a lower fraction of income being spent on consumption. Average job tenure, which can be considered as an (inverse) proxy for overall labour market flexibility, and employment protection are associated with a lower reduction of GDP during the crisis, as well as a somewhat smaller unemployment increase. Given the reduction of GDP, however, both a more flexible labour market and employment protection are associated with increased unemployment. This implies that the type of countries that have a less flexible labour market and more employment protection, experienced a smaller reduction of GDP and a slightly lower increase in unemployment, but a higher increase in unemployment than expected from the average relationship between GDP change and unemployment change based on Okun's law.

Unemployment of young workers differs greatly between countries. In 2007, prior to the crisis, the ratio between youth unemployment and unemployment of adults between 25 and 54 was 4.3 in Sweden (18.9 versus 4.4 percent), while in Germany the ratio was only 1.5, with unemployment rates of 11.7 versus 8.0 percent (OECD, 2010). Differences in relative unemployment of younger workers to a large extent reflect heterogeneity in the institutional framework. For example, Sweden has a strictly enforced last-in-first-out principle, whereas Germany has an apprenticeship system that makes it relatively easy for young adults to find a job after graduation (see Keeley and Love, 2010). Our data indicate that the ratio between youth unemployment and adult unemployment during the recession was relatively constant. For the countries in our sample, the average ratio changed from 2.8 to 2.9 (with a standard deviation of 0.6 including and 0.3 excluding Iceland). In Spain, youth (adult) unemployment increased from 18.2 (7.2) to 37.9 (16.5) percent between 2007 and 2009, in Ireland it increased from 10.0 (3.9) to 25.9 (10.8) percent. As all correlations between the pre-crisis ratio of adult and youth unemployment and our measures for the severity of the crisis are statistically insignificant, our findings suggest a substitution effect resulting in reduced effects of the crisis for the elderly at the cost of the young.

As shown in Table 2, trade union density has a statistically significant correlation with GDP change, but not with the change in unemployment. The relationship between these variables is also shown graphically in Figure 8. The result for GDP might be caused by a less flexible labour market, although it should be kept in mind that correlation does not necessarily imply causality. For example, wages could be higher and more difficult to adjust in countries with strong trade unions. This would explain why countries with higher labour union participation adapt more slowly to demand changes and experience a larger GDP decline. A decline in GDP generally also coincides with an increase in unemployment, since less labour is needed for production. On the other hand, labour unions provide employment protection, which can reduce the increase in unemployment. These two effects might 
compensate each other, which could explain why we do not find an effect of labour union membership on the unemployment change.

Figure 8. Change of GDP (upper panel) and unemployment (lower panel) and trade union membership.
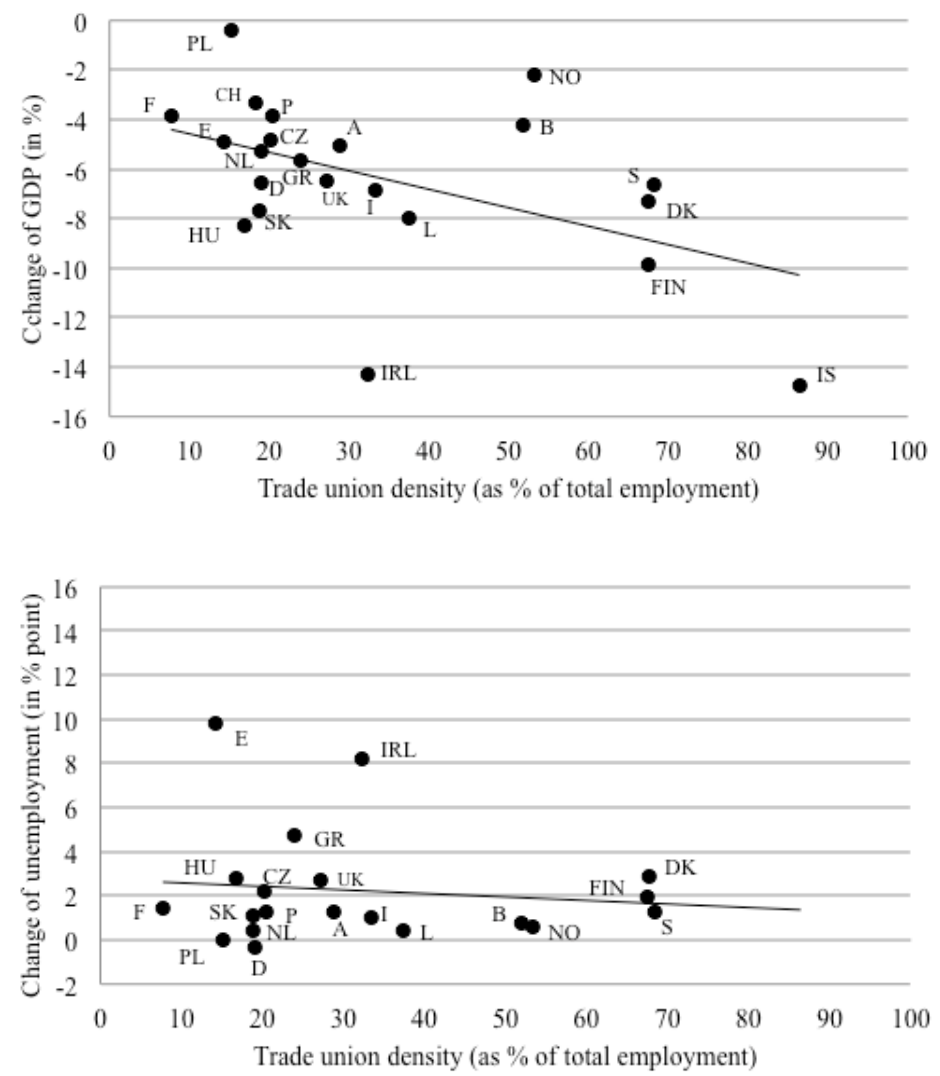

Note: See Appendix B for a list of abbreviations of countries

\subsection{Short-term work programmes and the crisis}

Following the start of the crisis, many governments adapted policy programmes aimed at reducing unemployment growth. Short-term work programmes have been developed by many European countries, allowing firms that face reduced demand to temporarily lay off workers. According to Hijzen and Venn (2010), this had a substantial impact on preserving jobs, especially in Germany. For the countries in our sample, we do not find a relation between GDP and the share of employees enrolled in short-term work programmes. We also find with respect to those programmes an insignificant negative effect on the change of unemployment during the crisis, and an even stronger (though still statistically insignificant) negative effect on the deviation from Okun's law. It must be noted that enrolment in short-term work arrangements - given the nature and conditions of the programme in each country - is highly endogenous, as more workers will enrol in countries experiencing a more severe recession. The deviation of unemployment from the level expected from the estimated association between unemployment change and GDP change is likely to be less affected by endogeneity, and is visualised in Figure 9. Even though short-term work programmes may have played some role in reducing 
unemployment, our data suggest that they provide far from a complete answer to the issue of crosscountry heterogeneity in unemployment.

Figure 9. Relationship between short-term work schemes and the deviation from Okun's law

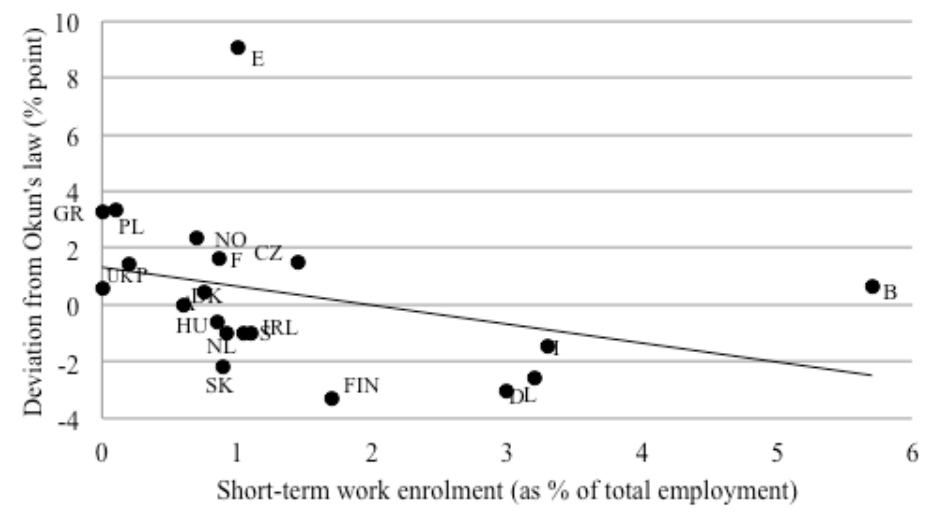

Note: See Appendix B for a list of abbreviations of countries

\section{National and regional relevance of sectoral composition}

\subsection{Sectoral composition and the national level}

The third determinant of crisis sensitivity in terms of GDP and unemployment that we take into account is the sectoral composition of an economy. Sectoral composition is the result of a complex interplay between demand and supply factors, comparative advantages and associated specialization patterns, labour market institutions and path dependencies (see, for example, Baumol, 1967, Rowthorn and Ramaswamy, 1997, and De Groot, 2000). The effect of a crisis can differ substantially across sectors. Most manufacturing sectors, for instance, tend to be much more affected by the business cycle than the services sectors. When a country or a region has a relatively large share of industries with a more than average sensitivity to the business cycle, they can - ceteris paribus - be expected to be affected relatively strongly during a recession.

We have estimated the crisis or recession sensitivity of 14 sectors by regressing for each sector for the aggregate of 17 countries in our sample, the annual growth in value added of each sector $\left(g_{s, t}\right)$ on the annual growth of the total GDP, excluding the sector itself, $\left(g_{e u, t}\right)$ :

$$
g_{s, t}=\alpha_{s}+\beta_{s} g_{e u, t}+\varepsilon_{s, t}
$$

The first run of regressions is based on the aggregate or EU-wide data for the EU-15, Norway and Switzerland. The data cover the period 1980-2003, so there are 23 observations for each sector (see Möhlmann et al., 2011, for a more extensive discussion of the sensitivity of European regions to the common European business cycle). 
The coefficient $\beta_{s}$ is an indicator for the average EU sensitivity of a sector for the EU wide business cycle. Table 3 shows the estimated coefficients for all 14 sectors. These results confirm that manufacturing sectors generally are more sensitivity to the business cycle than services sectors. The most sensitive sector is transport equipment: when the growth of the total economy is 1 percentage point higher, this sector is expected to grow an additional 2.5 percent. The estimated coefficients for agriculture and for mining and energy are negative and insignificant, which implies that the growth of these sectors is not linked to the overall business cycle. A possible explanation for this finding is that it is difficult to adjust the production capacity in these sectors. Another possible explanation is due to price effects. Value added has been deflated by a single deflator for each sector in each country. When price changes differ for inputs and outputs, this will affect real value added.

Table 3. Sectoral sensitivity for the business cycle, national level

\begin{tabular}{lcc}
\hline Sector & Observations & $\beta_{s}$ \\
Agriculture & 23 & $-0.01(0.99)$ \\
Mining and energy & 23 & $-0.46(0.32)$ \\
Food, beverages and tobacco & 23 & $0.91(0.00)$ \\
Textile and clothing & 23 & $1.67(0.00)$ \\
Fuels, chemicals, rubber and plastic products & 23 & $1.80(0.00)$ \\
Electronics & 23 & $2.15(0.00)$ \\
Transport equipment & 23 & $2.52(0.00)$ \\
Other manufacturing & 23 & $2.16(0.00)$ \\
Construction & 23 & $1.84(0.00)$ \\
Wholesale and retail & 23 & $0.86(0.00)$ \\
Hotels and restaurants & 23 & $0.94(0.00)$ \\
Transport and communications & 23 & $0.61(0.01)$ \\
Financial services & 23 & $0.66(0.04)$ \\
Other market services & 23 & $0.86(0.00)$ \\
Non-market services & 23 & $0.21(0.16)$ \\
\hline
\end{tabular}

Note: $p$-values are between parentheses.

The sectoral composition on the country level can now be combined with the sectoral sensitivities from Table 3 to connect the depth of a crisis to the sectoral composition (for the regional level we will follow a similar procedure in Section 4.2 below). The sectoral composition differs quite a lot across the EU countries as well as across the EU regions. Figure 10 shows the lowest, average and highest share for each of the 14 sectors in 2003 for the EU 15 members, Norway and Switzerland. 
Figure 10. Highest, lowest and average sector shares (2003, in \%)

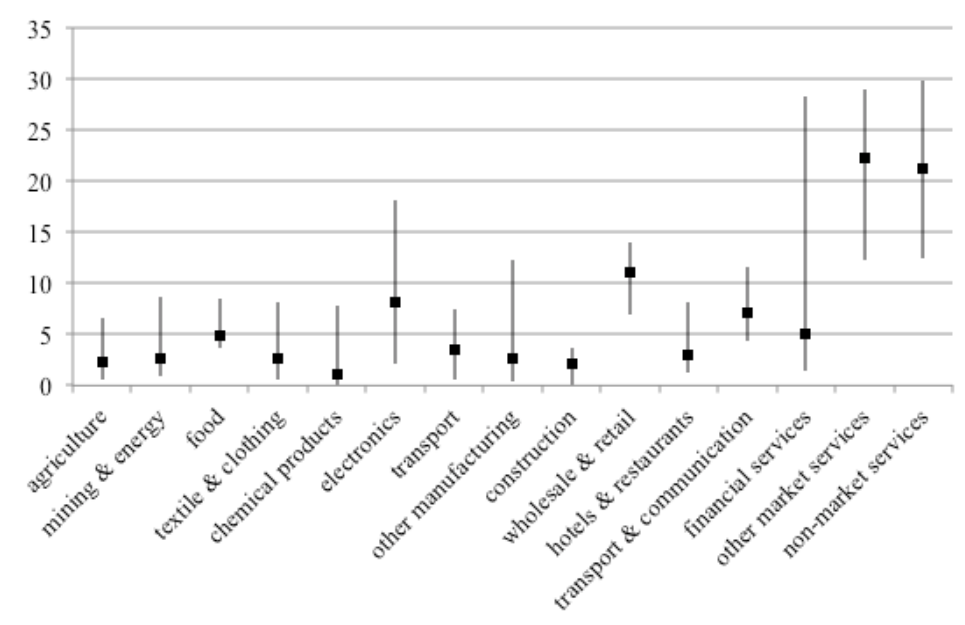

The largest sectors in these 17 countries are other market services (22.3 percent), non-market services (21.2 percent) and wholesale and retail (11.2 percent). The sectors with the lowest share are chemical products (1.1 percent), construction ( 2.1 percent) and agriculture (2.3 percent). A sector that has a particularly high variation between countries is the financial services sector, which accounted for more than 28 percent of the GDP in Ireland while only for 1.5 percent in Norway. These national differences in the sectoral composition might have a direct bearing on the impact of the fiscal austerity measures that are now in place in many of these countries following the 2008-crisis. Typically, the austerity measures contain large spending cuts that imply the loss of public sector jobs. As a result, a country might be more affected by it own austerity measures if it has a large value added share in the nonmarket services sector.

The part of the sensitivity of a country or region that is due to the sectoral composition can be estimated by taking the weighted average of the sectoral coefficients for $\beta_{s}$, based on the sector shares of the regions in 2003 shown by Table 3. The weighted averages for countries are shown in Table 4 . This table also shows the GDP growth in 2009 and the accumulated GDP loss in the first six quarters of the recession. This last indicator is calculated by summing the difference between the GDP level before the recessions started and the GDP level in each of the next six quarters. The starting period of the recession was determined for each country separately. 
Table 4. Sensitivity to the business cycle of countries

\begin{tabular}{llll}
\hline & & Growth & Cumulative \\
Country & Sensitivity & $2009, \%$ & GDP loss, $\%$ \\
Ireland & 1.18 & -7.6 & -11.2 \\
Finland & 1.01 & -8.0 & -10.1 \\
Austria & 0.98 & -3.9 & -5.1 \\
Sweden & 0.98 & -5.3 & -8.3 \\
Switzerland & 0.95 & -1.9 & -3.3 \\
Germany & 0.94 & -4.7 & -5.8 \\
Italy & 0.91 & -5.0 & -6.5 \\
Spain & 0.91 & -3.7 & -3.9 \\
Belgium & 0.90 & -2.8 & -4.3 \\
France & 0.89 & -2.6 & -3.7 \\
United Kingdom & 0.88 & -5.0 & -5.7 \\
Luxembourg & 0.86 & -3.7 & -7.2 \\
Portugal & 0.85 & -2.6 & -3.3 \\
The Netherlands & 0.80 & -3.9 & -4.1 \\
Denmark & 0.78 & -5.2 & -7.4 \\
Greece & 0.77 & -2.3 & -3.5 \\
Norway & 0.58 & -1.4 & -1.9 \\
\hline & & &
\end{tabular}

Table 4 shows that, based on the sectoral composition, it can be expected that Ireland will be most affected by changes in the European business cycle. The sectoral composition of Norway suggests that it is the least sensitive. These countries have indeed experienced the largest and the smallest decline of GDP during the crisis, which suggests that sectoral composition is indeed important.

If the sectoral composition is a good proxy for business cycle sensitivity, one would expect that these estimations are also a good explanation for the depth of the recent 2008 crisis. In order to test this, we compare the sensitivity estimations for countries, as presented in Table 4, with the growth in 2009 and with the accumulated GDP loss. The explanatory power of the estimated sensitivity is determined by regressing the growth in 2009 on the estimated sensitivity:

$$
g_{r, 2009}=\alpha+\beta \cdot S_{r, 2003}+\varepsilon_{r}
$$

Figure 11 contains two scatter plots that show the relationship between growth in 2009 and sensitivity (upper panel), and between accumulated GDP loss and sensitivity (lower panel). The regression results are shown in Table 5. 
Figure 11. Sectoral composition and depth of crisis for selected countries
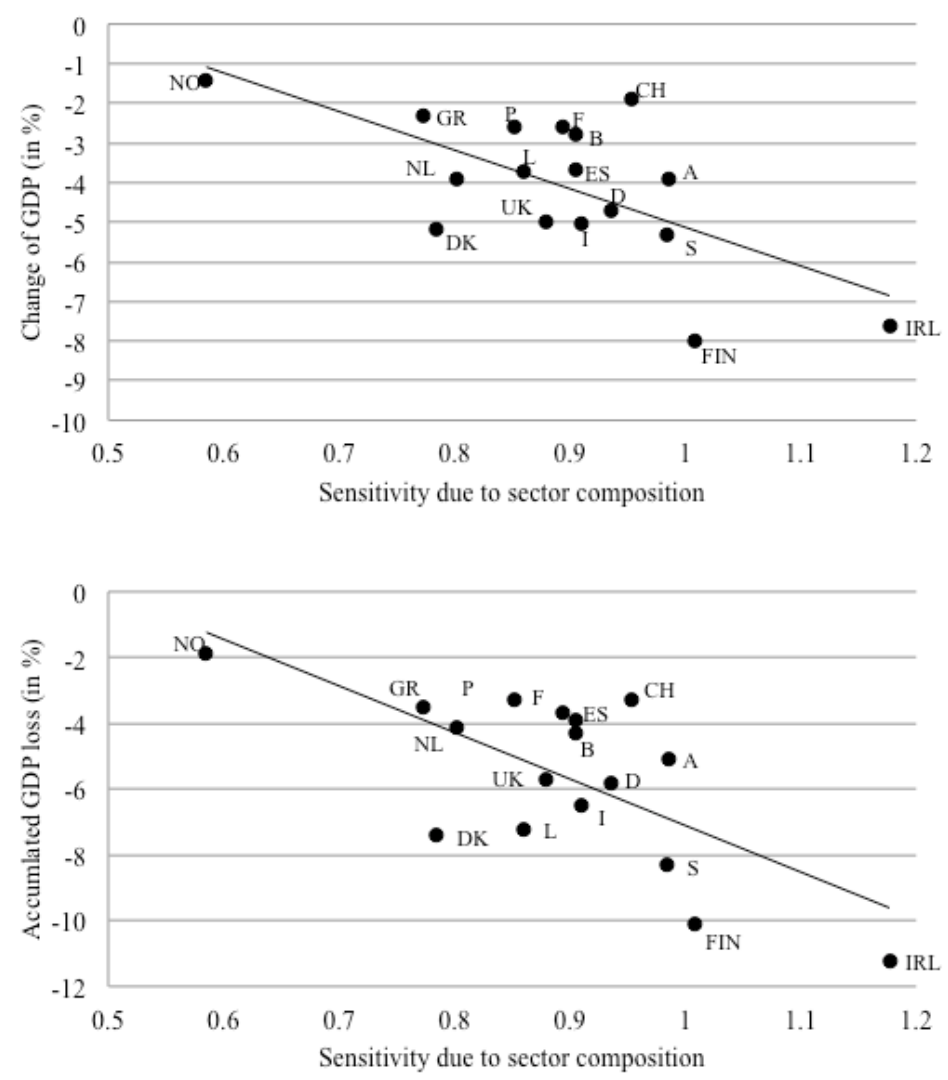

Note: See Appendix B for a list of abbreviations of countries

The findings suggest that the sensitivity, which was estimated based on the sectoral composition of the countries, explains a substantial part of actual change in GDP during the crisis. This is especially the case for the accumulated loss of wealth, which takes into account both the depth of the crisis and the duration. The number of observations in Table 5 is rather modest, which is also a reason to duplicate the sectoral composition analysis at the regional level.

Table 5. Regression results for sectoral composition of countries

\begin{tabular}{lrr}
\hline \multicolumn{1}{c}{ Dependent variable: } & Growth 2009 & Cumulative GDP loss \\
Sensitivity & $-9.8(0.00)$ & $-14.2(0.00)$ \\
Constant & $4.6(0.09)$ & $7.1(0.06)$ \\
Estimation method & OLS & OLS \\
Observations & 17 & 17 \\
$R^{2}$ & 0.44 & 0.47 \\
\hline
\end{tabular}

Note: $p$-values are between parentheses.

\subsection{Sectoral composition and the regional level}

We followed the same procedure with respect to the possible relevance of the sectoral composition on the 2008-crisis impact for European regions at the NUTS-2 level. The estimated sensitivities are shown in Figure 12 (the regional equivalent of Table 4 above). The regions with the highest estimated 
sensitivity are Southern and Eastern Ireland (1.20), Franche-Comté, France (1.15) and Småland med öarna, Sweden (1.15). The least sensitive regions are Groningen, Netherlands (0.43), Nord-Norge, Norway (0.51) and Hedmark og Oppland, Norway (0.51).

Figure 12. Sensitivity of the business cycle of regions
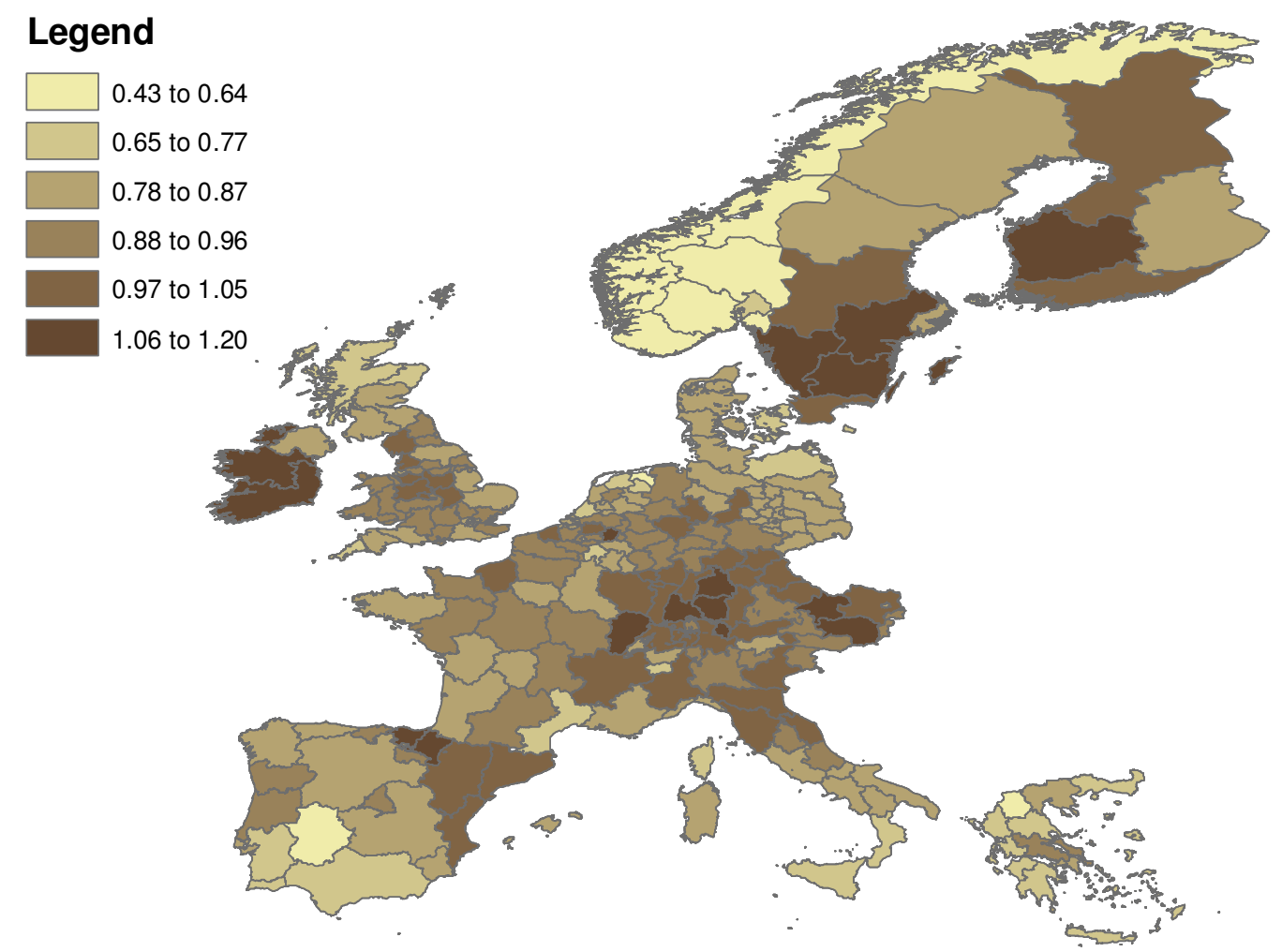

Unfortunately, regional growth data for 2009 are not yet available for all EU countries. Eurostat only provides annual data for regions up to the year 2007. We did, however, obtain provisional regional growth data for 2009 from the national statistic bureaus of 9 European countries, which enables us to do the analysis underlying Figure 8 and Table 5 at the regional level as well. These nine countries are Austria, France, Germany, Italy, Luxembourg, Netherlands, Spain, Switzerland, and the United Kingdom. The 2009 growth data for the regions in these nine countries are shown in Figure 13. The regions are either NUTS-1 or NUTS-2. Since these are annual data, we cannot determine the exact start of the recession for each region. However, almost all regions experienced a decline in GDP from 2008 to 2009 . We will therefore use the size of this decline as the indicator for the extent to which a region is affected by the global crisis. 


\section{Legend}
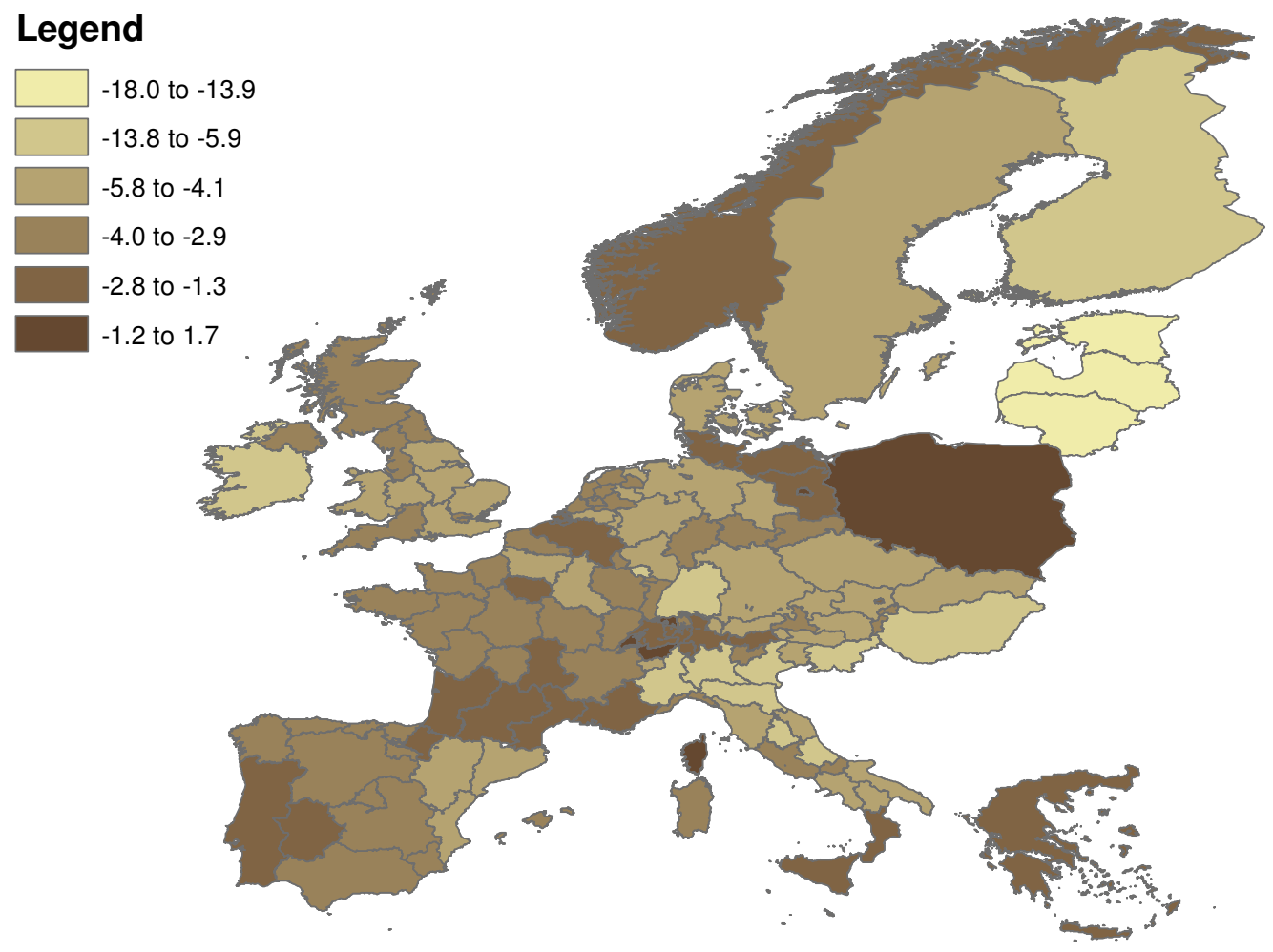

As far as the data are available, Figures 12 and 13 are fairly similar. The scatter plot below in Figure 14 also reveals that there seems to be a relationship between the growth in 2009 and the sensitivity based on the sectoral composition: a higher sectoral sensitivity goes along with a larger decrease in 2009 GDP regional growth.

Figure 14. Sectoral composition and change in regional GDP (2009, in \%)

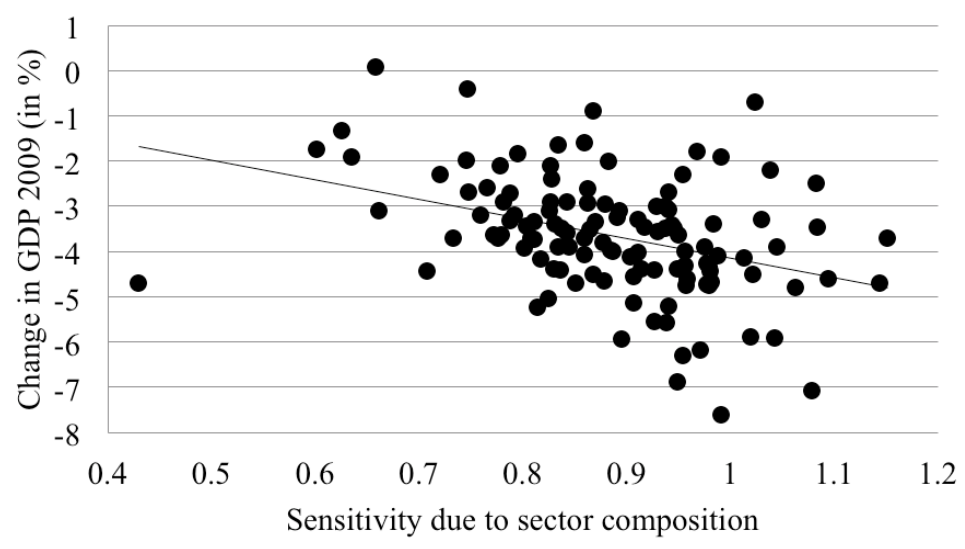


The outlier on the left in Figure 11 is identified as the Dutch province of Groningen. The reason for the low estimated sensitivity is that a very large share of the GDP of Groningen (almost 30 percent in 2003) comes from the sector mining and energy. This is due to the production of natural gas. As a companion to Table 5 with the national growth data, we have regressed the growth in 2009 on the estimated sensitivity with and without this outlier using equation (3). The results are shown in Table 6.

Table 6. Regression results for sectoral composition of regions

\begin{tabular}{lrr}
\hline Dependent variable: & Regional growth 2009 & Regional growth 2009 \\
Sensitivity & $-4.33(0.00)$ & $-5.36(0.00)$ \\
Constant & $0.18(0.84)$ & $1.12(0.23)$ \\
Estimation method & OLS & OLS \\
Outliers removed & None & Groningen (NL) \\
Observations & 119 & 118 \\
$\mathrm{R}^{2}$ & 0.14 & 0.19 \\
\hline
\end{tabular}

Note: $p$-values are between parentheses.

Based on the results in Table 6, there appears to be a quite strong relationship between the business cycle sensitivity of the region and the GDP growth in 2009: regions with more sensitive sectors experience a stronger growth decline in 2009. The sensitivity explains about 19 percent (excluding Groningen) of the variation in GDP growth. An increase of one unit of sensitivity is expected to coincide with 4.33 percent less GDP growth. Since the standard deviation of sensitivity is 0.12 , an increase of one standard deviation is associated with an additional decline of GDP in 2009 of 0.52 percent $(4.33 \mathrm{x} 0.12)$. Based on these estimations, the most sensitive region (Southern and Eastern Ireland, sensitivity of 1.2) is expected to decline 3 percent more than one of the least sensitive regions (Northern Norway, with a sensitivity of 0.5 ).

\section{Conclusions}

The aim of this paper was to describe and analyse the heterogeneous impact of the 2008 financial crisis and, above all, of the subsequent recession across European countries and regions, and to offer a preliminary investigation of the possible determinants of the cross-country and cross-regional variation in the impact of the crisis in terms of GDP and unemployment. In our attempt to decompose the spatial heterogeneity of the crisis, we considered three major possible determinants: financial markets and international trade linkages (or openness); institutions and policy; and sectoral composition. The paper certainly makes no claim to offer a full-fledged answer to the relevance of these (or other) determinants, but we do try to offer a number of relevant stylized facts about the cross-country and cross-regional differences of the latest crisis, making use of the most recent data at a relatively refined level of regional aggregation.

One of the best pre-crisis predictors for both the reduction of GDP and the change of unemployment in each country is the change of the ratio between GDP and labour costs per hour during the years prior to the crisis. On the account of financial linkages and international trade, our findings suggest that there is 
no strong relation with the severity of the crisis in different countries. This last answer does not depend on whether we look at exports in general, or exports to the United States, the country where the crisis started. Countries with large current account deficits prior to the crisis, however, have experienced more severe outcomes of the crisis. We also find limited evidence, in terms of correlation between institutions and the crisis impact, on the role played by (policy) institutions. Countries with a high incidence of trade union membership were confronted with relatively high reductions of GDP during the crisis (though it did not significantly affect unemployment). A higher government debt to GDP ratio is associated with a less severe reduction of GDP, and less change of unemployment during the recession. The sectoral composition of the economy - the role of which we investigate on the country level as well as on that of NUTS-1 and NUTS-2 regions - does seem to have a clear effect on the impact of the crisis. This applies to both countries and regions. Countries or regions with high shares of more cyclical sectors were indeed more affected by the crisis. The heterogeneity of regions with respect to their sectoral composition implies a different response to recessions or crises. This suggests that differentiated policies are warranted, rather than a one-size-fits-all approach. This also has implications for the discussion about the way fiscal austerity measures play out differently between the European countries and between European regions.

\section{References}

Baumol, W., 1967, Macroeconomics of unbalanced growth: the anatomy of urban crisis, American Economic Review, 57, pp. 415-426.

Cambridge Journal of Regions, Economy and Society, 2010 (special issue), The Resilient Region, Cambridge Journal of Regions, Economy and Society, 3(1), pp. 1-167.

Cerra, V. and S.C. Saxena, 2008, Growth dynamics: the myth of economic recovery, American Economic Review, 98(1), pp. 439-457.

Claessens, S., G. Dell'Ariccia, D. Igan and L. Laeven, 2010, Global linkages and global policies, Economic Policy, April 2010, pp. 267-293.

De Groot, H.L.F., 2000, Growth, unemployment and deindustrialization, Cheltenham: Edward Elgar.

De Groot, H.L.F., R. Nahuis and P.J.G. Tang, 2006, The Institutional Determinants of Labour Market Performance: Comparing the Anglo-Saxon Model and a European Style Alternative, in: W. Mitchell, J. Muysken and T. van Veen, Growth and Cohesion in the European Union, Cheltenham: Edward Elgar, pp. 157-179.

Fingleton, B., H. Garretsen and R. Martin, 2011, Recessionary Shocks and Regional Employment: Evidence on the Resilience of UK Regions, mimeo, Strathclyde/Groningen/Cambridge. 
Hijzen, A. and D. Venn, 2010, The role of short-term work schemes during the 2008-2009 recession, OECD Social, Employment and Migration Working Papers No. 115, Paris: OECD.

IMF, 2008, World economic outlook: Financial stress, downturns, and recoveries, Washington: IMF.

IMF, 2010, World economic outlook: rebalancing growth, Washington: IMF.

Kaminsky, G. and C. Reinhart, 1999, The twin crises: the causes of banking and balance of payments problems, American Economic Review, 89(4), pp. 473-500.

Keeley, B. and P. Love, 2010, From crisis to recession: the causes, course and consequences of the great recession, Paris: OECD.

Lane, P. and G.M. Milesi-Ferretti, 2010, The cross-country incidence of the global crisis, CEPR Discussion Paper, no. 7954, London: CEPR.

Martin, R., 2010, The Local Geographies of the Crisis: From Housing Bubble to Mortgage Meltdown and Beyond, Journal of Economic Geography, forthcoming.

Möhlmann, J.L., S.P.T. Groot and H.L.F. de Groot, 2011, De conjunctuurgevoeligheid van Europese sectoren en regio's (in Dutch), mimeo, VU University Amsterdam.

OECD, 2010a, Employment outlook: moving beyond the jobs crisis, Paris: OECD.

OECD, 2010b, Trade and Economic Effects of Responses to the Economic Crisis, Paris: OECD.

Prachowny, M.F.J., 1993, Okun's law, theoretical foundations and revised estimates, Review of Economics and Statistics, 75, pp. 331-336.

Reinhart, C. and K. Rogoff, 2009, The aftermath of financial crises, American Economic Review, Vol. 99, pp. 466-472.

Rose, A.K. and M.M. Spiegel, 2010, Cross-country causes and consequences of the crisis: an update, CEPR Discussion Paper, no. 7901, London: CEPR.

Rowthorn, R. and R. Ramaswamy, 1997, Deindustrialization: causes and implications, IMF Working Paper, WP/97/42, Washington: IMF.

Sharpe, S.A., 1994, Financial market imperfections, firm leverage, and the cyclicality of employment, American Economic Review, Vol. 84, pp. 1060-1074. 
Appendix A. Description and sources of data

\begin{tabular}{|c|c|c|}
\hline Variable & Source & Year (source) \\
\hline Change of GDP during recession & Eurostat & until Q2 2010 \\
\hline Change of unemployment during recession & Eurostat & until Q2 2010 \\
\hline Government support to financial institutions & OECD & 2007-2009 \\
\hline Housing price gap & $\mathrm{IMF}$ & $1997-2007$ \\
\hline Exports by destination as percentage of GDP & OECD & 2007 \\
\hline Imports by destination as percentage of GDP & OECD & 2007 \\
\hline Current account balance & Eurostat & 2004-2007 \\
\hline Unit labour costs & Eurostat & 2001-2007 \\
\hline Budget surplus as percentage of GDP & Eurostat & 2007 \\
\hline Government debt as percentage of GDP & Eurostat & 2007 \\
\hline Highest marginal tax rate (corporate) & Worldbank & 2009 \\
\hline Highest marginal tax rate (income) & Worldbank & 2009 \\
\hline Average job tenure & OECD & 2009 \\
\hline Share of temporary jobs & OECD & 2007 \\
\hline Share of government jobs & OECD & 2005 \\
\hline Strictness of employment protection & OECD & 2008 \\
\hline Spending on active labour market policies & Eurostat & 2008 \\
\hline Ratio between youth and adult unemployment & OECD & 2007 \\
\hline Trade union density & OECD & 2008 \\
\hline Product market regulation index & OECD & 2008 \\
\hline Enrolment in short-term work programmes & Hijzen and Venn (2010) & 2009 \\
\hline
\end{tabular}




\begin{tabular}{|c|c|}
\hline \multicolumn{2}{|c|}{ Appendix B. Country abbreviations } \\
\hline Country & Abbreviation \\
\hline Austria & A \\
\hline Belgium & B \\
\hline Bulgaria & BG \\
\hline Cyprus & $\mathrm{CY}$ \\
\hline Czech Republic & $\mathrm{CZ}$ \\
\hline Denmark & DK \\
\hline Estonia & EST \\
\hline Finland & FIN \\
\hline France & $\mathrm{F}$ \\
\hline Germany & $\mathrm{D}$ \\
\hline Greece & GR \\
\hline Hungary & $\mathrm{HU}$ \\
\hline Iceland & IS \\
\hline Ireland & IRL \\
\hline Italy & I \\
\hline Latvia & LV \\
\hline Lithuania & LT \\
\hline Luxembourg & $\mathrm{L}$ \\
\hline Malta & M \\
\hline Netherlands & NL \\
\hline Norway & NO \\
\hline Poland & PL \\
\hline Portugal & $\mathrm{P}$ \\
\hline Romania & RO \\
\hline Slovakia & SK \\
\hline Slovenia & SLO \\
\hline Spain & $\mathrm{E}$ \\
\hline Sweden & S \\
\hline Switzerland & $\mathrm{CH}$ \\
\hline United Kingdom & UK \\
\hline
\end{tabular}

